Pak. j. sci. ind. res. Ser. B: biol. sci. 2018 61B(2) 95-102

\title{
Population Density Estimates of Punjab Urial in Scrub Forest
}

\author{
Muhammad Irshad Arshad ${ }^{\text {a* }}$ and Anwar Hussain ${ }^{\mathrm{b}}$ \\ ${ }^{a}$ Department of Forestry, Range \& Wildlife, Ghazi University, Dera Ghazi Khan, Pakistan \\ ${ }^{\mathrm{b}}$ Punjab Wildlife Department, Lahore, Pakistan \\ (received May 25, 2016; revised May 5, 2017; accepted May 16, 2017)
}

\begin{abstract}
A ground survey of the population of Punjab urial (Ovis orientalis punjabiensis) was conducted in 2007 on transect lines following the distance sampling methodology in five localities of district Jhelum, Punjab, Pakistan. Its aim was to determine the population status with reference to trophy sized males. The estimated population density for 5 distinct survey areas (Kandal Un-classed Forest and Jalapur Wildlife Sanctuary, Phadial Reserved Forest, Nili South and Brali Reserved Forests, Lehri and Jindi Reserved Forests and Tilla Jogian Game Reserve). Per square kilometer of area, respectively was $1.26 \pm 0.49,1.30 \pm 0.56,0.46 \pm 0.19,0.36 \pm 0.15$ and $0.37 \pm 0.13$, and overall for combined data it was $0.63 \pm 0.14$. The male/female ratio indicated a preponderance of females over the males $(1: 2.53)$. The estimated mean group size was $5.08 \pm 0.44$. The study showed some indications of recovery in the population of Punjab urial in a context of increased protection efforts by the Punjab Wildlife Department in the recent past by the introduction of community-based trophy hunting in the area as a conservation and management tool.
\end{abstract}

Keywords: Punjab urial, Ovis vignei punjabiensis, distance sampling, line transect, population density

\section{Introduction}

Some studies have reported a decreasing trend in the populations of wild animals in Pakistan due to increasing human population pressure, destruction and degradation of habitats, poaching and mass killing of mammals and birds by commercial hunters and netters (Habiba et al., 2015; Khan et al., 2015; Iqbal et al., 2012; Awan, 2001; Chaudhry et al., 2001). The urbanization and developmental activities have also contributed to the fragmentation and degradation of the natural habitats.

Having seven species of sheep and goats (further divided into 12 subspecies), Pakistan is quite rich in diversity of wild Caprinae (Hess et al., 1997; Roberts, 1997; Mountfort, 1969). There are three subspecies of Urial Ovis vignei distributed in different ecological zones of the country (Shackleton, 1997) viz. (i) Blanford or Balochistan Urial (Ovis vignei blanfordi), (ii) Ladakh Urial (Ovis vignei vignei) and (iii) Punjab Urial (Ovis vignei punjabiensis). Amongst these, Punjab Urial, Ovis vignei punjabiensis Lydekker 1913 is an important biggame species distributed in hilly tracts between rivers Jhelum and Indus up to an altitude of $1500 \mathrm{~m}$ in the Kala Chitta and Salt Ranges in province of the Punjab, Pakistan (Hess et al., 1997; Mirza et al., 1980; Aleem, 1977; Schellar and Mirza, 1974). Its former range also included Margalla Hills and Khair-i-Murat Range areas.

*Author for correspondence; E-mail: hod.frw@gudgk.edu.pk
The Salt Range used to comprise about $84 \%$ of the historic range of the subspecies but in its present state the area within the Salt Range has been reduced up to $70 \%$ and in the entire range up to $73 \%$ of the historic distribution range (Awan et al., 2004). According to IUCN Red List of Pakistan Mammals, the subspecies is endangered (Sheikh and Molur, 2005) and declared vulnerable as in IUCN Red List of Threatened Species (IUCN, 2013). It is also listed in Appendix II of the CITES and legally protected under Punjab Wildlife (Protection, Preservation, Conservation and Management) Act 1974 (Hess et al., 1997). The erection of M-2 Motorway from Lahore to Islamabad has formed a substantial barrier to the free movement and dispersal of Punjab Urial in the Salt Range (Awan, 2006).

Pakistan has leaded the world in introducing the notion of community-based trophy hunting programmes (CTHP) for successful conservation of biodiversity in high alpine ecosystems (WWF-Pakistan, 2001). Limited trophy hunting has been in practice in Pakistan since 1980s in Baluchistan, Khyber Pakhtoonkhwah (former north west Frontier province), and Gilgit-Baltistan (formerly part of the Federally Administered Areas) provinces as a management tool for the conservation of Suleiman Markhor (Capra falconeri), Blanford or Balochistan Urial, Sindh Ibex (Capra hircus blythi), Flare-horned Markhor (Capra falconeri falconeri) and Himalayan Ibex (Capra ibex sibirica). The money 
received in the form of hunting fees has been utilized especially for the conservation of biodiversity in general, protection of the concerned species and to alleviate poverty in the local communities (Mir, 2006; Shackleton, 2001).

In recognition of the role of CTHPs and local communities in conservation in other parts of the country, Wildlife and Parks Department of provincial government of Punjab also started CTHP in collaboration with local communities for in-situ protection and conservation of Punjab Urial in the year 2006. For this purpose new rules and regulations were framed and many conservation oriented community based organizations (CBOs) were registered with the department to transparently implement CTHPs (Azam et al., 2006). The trophy hunting season has been fixed from December to February. Trophy sized male Urials were defined as those individuals whose horns had reached full development or attained the size of 26 inches or more. The trophies are being offered through international bidding. $80 \%$ of the trophy hunting fee is used for the protection of Punjab Urial and other wildlife species occurring in the area and for poverty alleviation efforts through CBOs (half of it to be spent on conservation activities like paying salaries of the staff hired for protection and law enforcement and bearing costs of the monitoring surveys, and the remaining half on community welfare) whereas the remaining $20 \%$ goes to the government.

The objectives of the present study were to (i) explore the distribution of Punjab Urial in the scrub forests of district Jhelum, Punjab, Pakistan (ii) obtain a baseline estimate of its population density, and (iii) obtain a baseline estimate of the number of trophy sized males in the population.

\section{Materials and Methods}

Study sites. The study was conducted in five scrub forest localities of the Jhelum district believed to have major population of Punjab Urial in the area viz. (1) Kandal-Jalalpur un-classed Forest and Wildlife Sanctuary $\left(41.69 \mathrm{~km}^{2}\right)$, (2) Phadial Reserved Forest $\left(44.31 \mathrm{~km}^{2}\right)$, (3) Nili South-Brali Reserved Forests $\left(103.06 \mathrm{~km}^{2}\right)$, (4) Lehri-Jindi Reservd Forests $\left(70.06 \mathrm{~km}^{2}\right)$ and (5) Tilla Jogian (Rohtas) Game Reserve (100.66 km²).

The area supports a dry sub-tropical semi-evergreen scrub forest (Champion et al., 1965) with the Blackwood Senegalia modesta (Wall.) P.J.H. Hurter (Syn. Acacia modesta) 'Phulai' (the trivial names in single quotes) and Wild olive Olea europaea L. subsp. cuspidata (Wall. ex G. Don) Cif. (Syn. Olea ferruginea) 'Kau' as dominant tree species. Blackwood was predominant on hotter aspects and sand stone terrain where it seemed to be the only tree species able to with stand excessive aridity. Often, it was found in association with Hopseed bush Dodonaea viscosa Jacq. 'Sanatha' and Gymnosporia royleana Wall. ex M.A. Lawson 'Pataki'. The wild olive was found practically everywhere in varying proportions, specifically dominant on lime stone landscape. In some places it occurred as pure stand while in others it was mixed with Blackwood, Hopseed bush and other auxiliary species. Hopseed bush was no doubt the most commonly occurring plant, found all around in small to fairly large patches. Other commonly encountered plant species were Malabar nut Justicia adhatoda L. 'Bahekar', Wildjujube Ziziphus nummularia (Burm. f.) Wight \& Arn. 'Mallah', Honeytree Tecomella undulata (Sm.) Seem. 'Lahura', Toothbrush tree Salvadora oleoides Decne. 'Jal', Honey mesquite Prosopis glandulosa Torr. and Gymnosporia royleana Wall. ex M.A. Lawson 'Pataki'. The most common grasses covering the forest ground were Southern crabgrass Digitaria bicornis (Lam.) Roem. \& Schult. 'Pharion', Hurricane grass Bothriochloa pertusa (L.) A. Camus 'Palwan', Golden-beard grass Chrysopogon fulvus (Spreng.) Chiov. (Syn. Chrysopogon montanus) 'Khar', Khavi grass Cymbopogon jwarancusa (Jones) Schult. 'Khawi', Black spear grass Heteropogon contortus (L.) P. Beauv. ex Roem. \& Schult. 'Suriala'. Ochthochloa compressa (Forssk.) Hilu (Syn. Eleusine compressa) 'Chimber', Annual-bristle grass Aristida adscensionis L. (Syn. Aristida depressa) 'Lumb', Bermuda grass Cynodon dactylon (L.) Pers. 'Khabbal' and Munj grass Saccharum griffithii Munro ex Boiss. 'Sarkanda'.

The climate of the area is extreme, very cold winters and very hot summers. The average monthly temperature ranges from 5.9 to $38.4{ }^{\circ} \mathrm{C}$, with January coldest and June hottest month of the year. During winters the temperature often drops to below zero in December and January. The rainfall differs with season, about $60 \%$ occurrs during the monsoon, June through September (Frisina et al., 2007), 25\% in winter, January through April (Awan et al., 2006) and the remaining 15\% occurs irregularly during remaining months of the year. The mean annual rainfall varies from 48 to $69 \mathrm{~mm}$ in different parts of the district. 
Methods. Even after a long history of developments in surveys planning and improvements in census methods, the population census and survey still remain a hard work for the wildlife biologists and managers (Pollock et al., 2002; Buckland et al., 2000; Schwarz and Seber, 1999; Wilson et al., 1996). Population census of wild ungulates is troublesome in the mountainous terrain because of their shyness and excellent sense of olfaction to perceive human smell over long distances (Brohi, 2006; Roberts, 1997). The standard distance sampling survey methodology was followed after Buckland et al. (2001), with varying transect length 4 to $12 \mathrm{~km}$ and recorded perpendicular distance and group size for every sighting and the data were analyzed with the help of computer software Distance 6.0 Release 2 (Thomas et al., 2009). The study was conducted in 2007. The experienced staff from wildlife department and private personnel from the community based organization (CBOs) was deployed to conduct simultaneous field surveys in a given forest locality to avoid double counting to the possible extent. Transect routes were predefined and the survey teams, consisting of 2 to 3 persons each, reached the starting point on foot and or by vehicles before the sunrise/start of the survey. The time of the survey was from 5.30 am to $9.00 \mathrm{am}$ in the morning and $5.00 \mathrm{pm}$ to $6.45 \mathrm{pm}$ in the evening. The sightings of Punjab Urial were made on both sides of the transact line during walking the mountain ridges with naked eye or with the aid of $8 \times 40$ or $10 \times 40$ binoculars. From each sighting, the information recorded was, sex of the individuals, group size and type. The identified duplicate sightings were ignored to reduce error. Apart from utmost care in recording the data, some incon-gruence might had occurred with respect to double counting and in recording sex of the animal for the reason that yearling males and ewes looked very much similar except for minor differences in their size.
The density was calculated with the Distance Software 6.0 and the total population size computed from this value by multiplying the density with the area of the given forest. The individuals, whose sex could not be identified with certainty during field observations, were considered as unclassified; these were encompassed in estimation of population density but eliminated in determining population structure.

\section{Results and Discussion}

Population density. During this study, 60 observations on Urial heads were made along 36 transacts; 11 transacts in Phadial area with 20 observations, 7 transects each from Kandal-Jalalpur and Tilla Jogian areas with 14 and 9 observations, respectively, 6 transects from NliBrali area with 10 observations and 5 transacts from Lehri-Jindi area with 7 observations (Table 1). Computer software distance 6.0, Release 2 and the Estimator Model, Half-normal key, k(y) = Exp $(-\mathrm{y} * * 2 /(2 * \mathrm{~A}(1) * *$ 2)) based on minimum AIC (Akaike Information Criterion) was used to analyze the transect sampling data to estimate density of Urial population. The software ran with the warning messages that the Parameter 1 was near an upper bound and the parameters were being constrained to obtain monotonicity. The results have been summarized in Table 1. The Phadial Reserved Forest had densest Punjab Urial population with 1.30 heads per square kilometer followed by Kandal Unclassed Forest-Jalalpur Wildlife Sanctuary, Nili SouthBrali Reserved Forests, Tilla Jogian (Rohtas) Game Reserve and Lehri-Jindi Reservd Forests with the estimated density of $1.26,0.46,0.37$ and 0.36 individuals per square kilometer, respectively. The area had an overall density of 0.63 individuals per square kilometer (Table 1). Based on these density estimates, the habitat of Punjab Urial in Jhelum district can be classified in two categories, a high density area, comprising Phadial

Table 1. Population density of Punjab Urial, estimated by the computer software distance 6.0, in five forests of Jhelum district of the Punjab, Pakistan and the extrapolated population on the basis of those density estimates during 2007

\begin{tabular}{llllll}
\hline \hline $\begin{array}{l}\text { Name of } \\
\text { forest }\end{array}$ & $\begin{array}{l}\text { No. of } \\
\text { tran. }\end{array}$ & $\begin{array}{l}\text { No. of } \\
\text { obs. }\end{array}$ & $\begin{array}{l}\text { Cluster size } \\
\text { Mean } \pm \text { SE }\end{array}$ & $\begin{array}{l}\text { Density } \pm \text { SE } \\
\text { (per sq. km) }\end{array}$ & $\begin{array}{l}\text { Conf. inter. } \\
(95 \%)\end{array}$ \\
\hline Kandal-Jalalpur & 7 & 14 & $5.50 \pm 1.05$ & $1.26 \pm 0.49$ & $0.58-2.75$ \\
Phadial & 11 & 20 & $6.15 \pm 0.90$ & $1.30 \pm 0.56$ & $0.56-3.04$ \\
Nili South-Brali & 6 & 10 & $4.50 \pm 0.69$ & $0.46 \pm 0.19$ & $0.20-1.05$ \\
Lehri-Jindi & 5 & 7 & $3.71 \pm 0.71$ & $0.36 \pm 0.15$ & $0.15-0.86$ \\
Tilla Jogian & 7 & 9 & $3.78 \pm 0.83$ & $0.37 \pm 0.13$ & $0.18-0.75$ \\
Over all & 36 & 60 & $5.08 \pm 0.44$ & $0.63 \pm 0.14$ & $0.41-0.97$ \\
\hline \hline
\end{tabular}


forest and Kandal unclassed Forest and Jalalpur Wildlife Sanctuary and a low density area, comprising of Nili South and Brali Reserved Forests, Lehri and Jindi Reserved Forests and Tilla Jogian (Rohtas) Game Reserve.

Though, documentation of the occurrence of Punjab Urial in the study area can be dated back to as early as 1621 with reference to a hunt of Emperor Noor-ud-Din Muhammad Jehangir (Quddussi, 1970), nothing is on record about the size of the population with certainty till the recent past. Only qualitative observations of hunters, naturalists and expeditions to the area suggest that the animal was plentiful towards the early 1900 s (Awan et al., 2004). The known population estimation attempts for the subspecies have been summarized in Table 2. Schaller (1977) for the first time guessed that the world population of the subspecies may not exceed 2000 heads. Mirza et al. (1980) estimated 2157 animals in the whole range of its distribution, with 588 occurring in Jhelum district. For Jhelum area, the population estimates by Chaudhary et al. (1988) with 184 and 169 Urial heads in 1986 and 1987, respectively indicated a sharp decline in the population. The estimation by Azam et al. (2006) and the present study however indicated a promising recovery in the population of the subspecies. Our results also agree in partial with Edge and OlsonEdge (1987) who reported that a density of Urial between $1.7 / \mathrm{km}^{2}$ to $2.5 / \mathrm{km}^{2}$ in Kirther National Park, province of Sindh, Pakistan may be considered as a higher density for the area. However, these comparisons may not be considered as true comparisons representing the population trend due to the reason that all of these studies used somewhat different survey and computing methodologies.

In the last few decades, important developments have been made in theory and computing methods for the estimation of wildlife populations based on distance sampling techniques. The Distance Software (Thomas et al., 2009) has been made available for those who are interested in the study and conservation of biological populations. It is recommended that a comprehensive study may be launched to eventually assess the status of the subspecies throughout its distribution range with known certainty by using standard distance sampling and computing methodology and then in the light of that assessment the management of the species may be planned for its conservation and sustainable harvest in the form of CTHP in the long term.

Population structure. The group/herd size ranged from $1-17$ in the area with a mean $5.08 \pm 0.44$ and was found positively correlated with the population density $(r=$ 0.926 ), greater the population density, larger the group size as also reported by Awan et al. (2006). The estimated mean group size for Phadial, Kandal-Jalalpur, Nili South-Brali, Tilla Jogian and Lehri-Jindi, respectively was $6.15 \pm 0.90(\mathrm{n}=20), 5.50 \pm 1.05(\mathrm{n}=14), 4.50 \pm$ $0.69(\mathrm{n}=10), 3.78 \pm 0.83(\mathrm{n}=9)$ and $3.71 \pm 0.71(\mathrm{n}=$ 7) and combined for all the areas it was $5.08 \pm 0.44(\mathrm{n}$ $=60$ ), (Table 1). Most of the animals however occurred in small groups of 3-4 (Fig. 1). Mixed groups having

Table 2. Summary of documented population of Punjab Urial for parts of its distribution range

\begin{tabular}{|c|c|c|c|c|c|c|}
\hline \multirow[t]{2}{*}{ Source } & \multirow[t]{2}{*}{ Survey year } & \multicolumn{5}{|c|}{ Region of the distribution range } \\
\hline & & $\begin{array}{l}\text { Total range } \\
\left(5143 \mathrm{~km}^{2}\right)\end{array}$ & $\begin{array}{l}\text { Salt range } \\
\left(1265 \mathrm{~km}^{2}\right)\end{array}$ & $\begin{array}{l}\text { Jhelum Dist. } \\
\left(341 \mathrm{~km}^{2}\right)\end{array}$ & $\begin{array}{l}\mathrm{KGR}^{\mathrm{a}} \\
\left(137 \mathrm{~km}^{2}\right)\end{array}$ & $\begin{array}{l}\mathrm{KCR}^{\mathrm{b}} \\
(?)\end{array}$ \\
\hline Mountfort, 1969 & - & - & - & - & 500 & - \\
\hline Schaller and Mirza 1974 & - & - & 500 & - & - & - \\
\hline Schaller, 1977 & 1977 & 2000 & - & - & - & $60^{\mathrm{d}}$ \\
\hline Mirza et al., 1980 & 1979 & 2157 & - & 588 & 1288 & 213 \\
\hline Chaudhary et al., 1988 & 1986 & 733 & - & 184 & - & - \\
\hline Chaudhary et al., 1988 & 1987 & 528 & - & 186 & - & - \\
\hline Hess et al., 1997 & 1988 & - & - & - & 700 & - \\
\hline Chaudhary, 1992 (Unpublished) & 1992 & 1550 & - & - & $850^{\mathrm{e}}$ & - \\
\hline Awan et al., 2004 & 2000 & 1000 & 860 & $160^{\mathrm{f}}$ & 500 & - \\
\hline Azam et al., 2006 & 2005 & - & - & $210^{\mathrm{g}}$ & - & - \\
\hline Present study & 2007 & - & - & $215^{\mathrm{h}}$ & - & - \\
\hline
\end{tabular}

${ }^{\mathrm{a}}$ Kalabagh game reserve; ${ }^{\mathrm{b}}$ Kala Chitta Range; ${ }^{\mathrm{d}} \mathrm{Chak}$ Jabbi Area; ${ }^{\mathrm{e}}$ Hess et al., 1997; ${ }^{\mathrm{f}}$ Eastern salt range; ${ }^{\mathrm{g}}$ Jalalpur wildlife sanctuary; 26.6 sq. $\mathrm{km}$ and 44 sq. $\mathrm{km}$ adjacent to it; ${ }^{\text {h}}$ Estimate developed from density computed by distance 6.0. 
male, female and young were commoner than the pure male or pure female groups. The observed sex ratio was biased in favor of females varying from 1.15 females to each male at Kandal-Jalalpur Un-classed Forest and Wildlife Sanctuary, 2.27 to each male in Phadial Reserved Forest, 5.5 females to each male in Nili SouthBrali Reserved Forests; 2.4 females to each male LehriJindi Reservd Forests, 4 females to each male at Tilla Jogian (Rohtas) Game Reserve, overall there were 2.53 females to each male. About 63 per cent area was covered during survey and it was observed that the population of Punjab Urial was widely scattered all over the study areas.

A significant number of lambs were observed in the population but their proportion varied from one study area to the other. The lambs which observed were, 5 in Kandal-Jalalpur Un-classed Forest and Wildlife Sanctuary, 29 in Phadial Reserved Forest, 5 in Nili South-Brali Reserved Forests, 2 in Lehri-Jindi Reservd Forests and 7 in Tilla Jogian (Rohtas) Game Reserve. The higher percentage of lambs in Phadial Reserved Forest area may be considered as an indicator of increasing population and could have been a result of reproductive efficiency of the species or protective measures against lamb picking adopted by local CBO or more correctly a combination of both these factors.

Being largest intact population, Punjab Urial is very important from a conservation standpoint (Awan et al., 2004) and poverty alleviation in the local communities

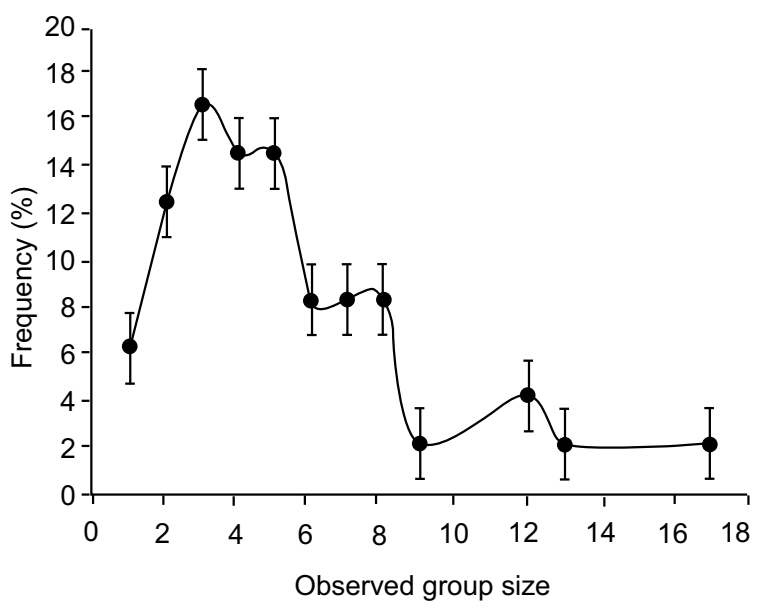

Fig. 1. Proportions of different group (herd) sizes in Punjab Urial with standard error, as observed in Jhelum district of Punjab, Pakistan in 2007. through implementation of CTHPs. For sustainable trophy hunting, initial requirement is to establish safe annual hunting quota in order not to affect population of a species negatively through artificial selection by hunting males having larger horns; such effects known for some species in other parts of the world. For most of the mountain sheep species, annual harvest of trophy sized males equal to two percent of the total population is considered safe, without adverse effects on the population (Frisina et al., 2007; Harris, 1993). Wegge (1997) suggests an annual harvest of 10-20 per cent of the trophy sized segment as safe for stable and increasing population of most wild sheep. Thus from the population of Punjab Urial in Jhelum district, an annual harvest of up to four trophies could be considered safe. Elimination of these males is implausible to influence the generative ability of the population, or has a significant impact on population genetics of the Punjab Urial in the area and therefore a negligible effect on overall population size (Shackleton, 2001; Baker, 1997; Morrill, 1993). The Punjab Urial, like other wild sheep has espoused a polygynous mating system (Shackelton, 2001; Roberts, 1997). The population's entire reproductive efficiency depends on a small number of males and therefore wouldn't be influenced by loss of a small number of aged males (Caughley, 1977). However, it is again suggested that a regular monitoring of this population Punjab Urial following standard survey and computational methodology should be practiced for safe harvest of trophies in the long term in the interest of continuous survival of the species.

It was observed during the survey that Punjab Urial favoured the use of rugged and cliffs landscape similar to the selection of steep slopes and bare rocks by Blue Sheep (Pseudois nayaur) in Helan Mountains (Feng et al., 2006; Liu et al., 2005), mainly for the reason that cliffs offer an ideal place for mountain ungulates to protect themselves from predators (Oli, 1994). The Punjab Urial's preference for steep slopes and bare rocks can also be attributed to the predation pressures in the area caused by natural predators (Awan et al., 2006) like Indian Wolf (Canis lupus), Asiatic Jackal (Canis aureus) and Panther (Panthera pardus). It was also observed that major part of the habitat used by Punjab Urial was also exploited by domestic goats, sheep and cattle. Such multi-species habitat exploitation leads to overgrazing and destruction of palatable plant species and consequential severe inter-specific competition for available food resources (Feng et al., 2006). 
Another important factor in the area has been almost three fold increase in human population in the Salt Range (including Jhelum district) in last 50 years. This increased urbanization had far reaching effects on forest and other natural resources utilization (Awan et al., 2004). The recovery of the population of Punjab Urial in the Jhelum district under these unfavorable conditions may be regarded as a good sign and be attributed to the adaptive potential of the species. The protection measures must be further strengthened through efficient and strict law enforcement for population recovery of the species to continue and its survival for the times to come. An awareness campaign should also be launched to educate local communities with respect to the importance of conservation of Punjab Urial and other natural resources, and create a sense of their ownership amongst them. It is presumed that when communities are given detailed training about the resources under their control, taught effective and sustainable management practices, and trained in institutional management structures, they will be able to manage natural resources in their areas in a sustainable way and on their own.

The population of Punjab Urial should be monitored regularly, surveyed once every year, to have fair knowledge of its increasing or decreasing trend along with the possible threats to the species to ensure the continued survival of the subspecies in its natural range. Many ecologists and conservationists are of the view that one of the best expectation for protecting and conserving natural resources is to engage local communities near protected areas and the remnant seminatural areas. The local communities are dependent on these resources for their survival and it is to their own benefit to protect those areas for the forthcoming uses (USAID, 2008). Even at this preliminary stage, observed data on the population of Punjab Urial shows that conservation by the local communities has revealed promising outcomes. Communities based wildlife management programme also is cost effective for the government. Therefore, participation of local communities in the conservation and management of Punjab Urial (Hussain et al., 2015) should be encouraged for the sustainability of subspecies and generation of income for communities through trophy hunting. Because of sub-aridian nature of habitat in the area, dry periods are limiting for the existence of wildlife species in general as well as the population of Punjab Urial (Chaudhry et al., 1997). Therefore, it is almost essential to build storage ponds at appropriate places in the area to retain water for the animals to drink during drought periods. This practice has given encourging results in the constancy of ungulate populations in the Kirther and Chilton-Hazar Gangi National Parks (Brohi, 2006) respectively in the provinces of Sindh and Baluchistan in the countary.

\section{Acknowledgement}

We are grateful to Punjab Wildlife Department staff of district Jhelum for completing the study. We are also thankful to Mr. Muhammad Habib, Incharge Wildlife Watchers, CBO Beher Faquiran for providing us assistance and cooperation during the surveys.

\section{References}

Aleem, A. 1977. Punjab Urial in Chak Jabbi Area- Kala Chitta Range. Pakistan Journal of Forestry, 27: 130-138.

Awan, G.A. 2006. Conservation of Punjab Urial (Ovis vignei punjabiensis) through long-term monitoring of marked individuals. A report to the The Rufford Maurice Laing Foundation, London, UK.

Awan, G.A., Festa-Bianchet, M., Ahmad, T. 2006. Poaching, recruitment and conservation of Punjab urial Ovis vignei punjabiensis. Wildlife Biology, 12: 443-449.

Awan, G.A., Ahmad, T., Ashraf, S. 2004. On the distribution of Punjab urial (Ovis vignei punjabiensis). Records Zoological Survey of Pakistan, 15: 1-6.

Awan, G.A. 2001. Pet trade threatened endangered urial. Caprinae, Newsletter. IUCN, Caprinae Specialist Group (CSG), Canada.

Azam, M.M., Nazar A.Q., Abbas, N. 2006. Studies on population status of Punjab Urial (Ovis vignei punjabiensis) in Jalalpur, district Jhelum. Records Zoological Survey of Pakistan, 17: 1-6.

Baker, J.E. 1997. Trophy hunting as a sustainable use of wildlife resources in southern and eastern Africa. Journal of Sustainable Tourism, 5: 306-321.

Brohi, M.A. 2006. Status of Urial, Ibex and Chinkara in Durreji, Balochistan. Records Zoological Survey of Pakistan, 17: 11-14.

Buckland, S.T., Goudie, I.B.J., Borchers, D.L. 2000. Wildlife population assessment: Past developments and future directions. Biometrics, 56: 1-12.

Chaudhry, A.A., Agha, I.I., Hussain, A., Ahmad, R., Hameed, M. 1997. Biodiversity in a typical sub mountainous protected area - Chumbi-Surla Wildlife Sanctuary, Punjab, Pakistan. In: Biodiversity of 
Pakistan, S. A. Mufti, C. Woods, S. A. Hasan (eds.), pp. 63-79. Pakistan Museum of Natural History, Islamabad and Florida Museum of Natural History, Gainesville, USA.

Chaudhary, A.A., Khalid, U., Chaudhry, S.A. 1988. Urial population in the Punjab. In: Proceeding of the $8^{\text {th }}$ Pakistan Congress of Zoology, pp. 201-204, Zoological Society of Pakistan, Lahore, Pakistan.

Caughley, G. 1977. Analysis of Vertebrate Populations, 234 pp., John Wiley and Sons, New York, USA.

Champion, S.H., Seth, S.K., Khattak, G.M. 1965. Forest Types of Pakistan. 238 pp., Pakistan Forest Institute, Peshawar, Pakistan.

Edge, W.D., Olson-Edge, S.L. 1987. Ecology of Wild Goats and Urial in Kirthar National Park. A final report. Montana Cooperative Wildlife Research Unit, University of Montana, Missoula, USA.

Feng, X.U., Ming, M.A., Yi-qum, W.U. 2006. Population density and habitat utilization of Ibex (Capra ibex) in Tomur National Nature Reserve, Xinjiang, China. Zoological Research, 28: 53-55.

Frisina, M.R., Awan, G.A., Woodford, M.H. 2007. Determining trophy harvest quotas through a status survey of Urial (Ovis orientalis) in the Kalabagh Game Reserve, Punjab, Province Pakistan. Journal of the Bombay Natural History Society, 104: 3539.

Habiba, U., Anwar, M., Hussain, I., Rais, M. 2015. Population density and habitat status of Punjab urial (Ovis vignei punjabiensis) in Diljabba-Domeli game reserve, Punjab Pakistan. Journal of Animal and Plant Sciences, 25: 650-655.

Harris, R.S. 1993. Wildlife Conservation in Yeniuqou, Qinhal China. Post Doctoral Thesis, University of Montana, Missoula, MT, USA.

Hess, R., Bollman, K., Rasool, G., Chaudrhy, A.A., Virk, A.T., Ahmad, A. 1997. Indo Himalayan Region, 8.5 Pakistan. In: Wild Sheep and Goats and their Relatives: Status Survey and Conservation Action Plan for Caprinae, D. M. Shackleton (ed.), pp. 239-259, IUCN, Gland, Switzerland and Cambridge, UK.

Hussain, I., Munir, M., Anwar, M. 2015. Food habits of Punjab urial, Ovis vignei punjabiensis Lydekker, 1913, in Chumbi Surla Wildlife Sanctuary, Chakwal, Pakistan. Acta Zoologica Bulgarica, 67: 507-514.

Iqbal, M., Saleem, M.Z., Khan, M.A., Akhtar, M., Mahmood, K. 2012. Urial (Mammalia, Bovidae, Caprini) from the Kala Chitta range of northern
Pakistan. Punjab University Journal of Zoology, 27: 61-73.

Khan, W.A., Ahmed, M.S., Yaqub, A., Ali, H., Arshad, M. 2015. Distribution and population status of Punjab Urial, Ovis vignei punjabiensis (Mammalia: Bovidae), in Soan Valley, Salt Range, Punjab, Pakistan. Journal of Animal and Plant Sciences, 25: 851-859.

Liu, Z.S., Gao, L.R., Wang, X.M., Li, T., Li, Z.G. 2005. Winter bed site selection by blue sheep (Pseudois nayaur) in Helan Mountains. Zoological Research, 26: $580-589$.

Mir, A. 2006. Impact Assessment of Community based Trophy Hunting in MACP Areas of NWFP and Northern Areas. 38 pp., Report for the Mountain Area Conservancy Project, IUCN Pakistan.

Mirza, Z.B., Aslam, M., Asghar, M., Mehal, A.Q. 1980. Distribution, status, habitat and food of the urial in the Punjab. Journal of the Bombay Natural History Society, 76: 423-430.

Morrill, W.I. 1993. The Tourist Safari Hunter's Role in Conservation. 8 pp., Working Paper, Safari Club International, Herndon, Virginia.

Mountfort, G. 1969. The Vanishing Jungle. 286 pp., Collins, London, UK.

Oli, M.K. 1994. Snow leopards and blue sheep in Nepal: densities and predator: prey ratio. Journal of Mammalogy, 75: 998-1004.

Pollock, K.H., Nichols, J.D., Simons, T.R., Farnsworth, G.L., Bailey, L.L., Sauer, J.R. 2002. Large scale wildlife monitoring studies: statistical methods for design and analysis. Environmetrics, 13: 105-119.

Quddussi, E. 1970. Tauzik-i-Jehangiri. Majlasia Tarraki Adab, Lahore, Pakistan.

Roberts, T.J. 1997. The Mammals of Pakistan. 525 pp., Oxford University Press, New York, USA.

Schaller, G.B. 1977. Mountain Monarchs: Wild Sheep and Goats of the Himalaya. 425 pp., University of Chicago Press, Chicago, IL, USA.

Schaller, G.B., Mirza, Z.B. 1974. On the behavior of Punjab urial (Ovis orientalis punjabiensis). In: The Behaviour of Ungulates and its Relation to Management, V. Geist, F. Walther (eds.) pp. 306-323, IUCN, n_24, Morges, Switzerland.

Schwarz, C.J., Seber, G.A.F. 1999. Estimating animal abundance - Review III. Statistical Science, 14: 427-456.

Shackleton, D.M. 2001. A Review of Community-based Trophy Hunting Programs in Pakistan. 58 pp., IUCN-Pakistan, Islamabad. 
Shackleton, D.M. 1997. Social maturation and productivity in bighorn sheep: Are young males incompetent -? Applied Animal Behaviour Science, 29: $173-184$.

Sheikh, K.M., Molur, S. 2005. Status and Red List of Pakistan's Mammals. 344 pp., IUCN Pakistan.

Thomas, L., Laake, J.L., Rexstad, E., Strindberg, S., Marques, F.F.C., Buckland, S.T., Borchers, D.L., Anderson, D.R., Burnham, K.P., Burt, M.L., Hedley, S.L., Pollard, J.H., Bishop, J.R.B., Marques, T.A. 2009. Distance 6.0. Release 2. Research Unit for Wildlife Population Assessment, University of St. Andrews, UK.

USAID, 2008. Nigeria Biodiversity and Tropical Forestry Assessment. Maximizing Agriculture Revenue in Key Enterprises for Targeted Sites
(Markets). United States Agency for International Development, USA.

Wegge, P. 1997. Preliminary guidelines for sustainable use of wild caprins. In: Status Survey and Conservation Action Plan for Caprinae, D. M. Shackleton (ed.), pp. 365-372, IUCN, Gland, Switzerland \& Cambridge, UK.

Wilson, D.E., Cole, F.R., Nichols, J.D., Rudran, R., Foster, M.S. 1996. Measuring and Monitoring Biological Diversity. Standard Methods for Mammals. 409 pp., Smithsonian Institution Press Washington, DC, USA.

WWF-Pakistan. 2001. Trophy Hunting Guideline and Procedures in Northern Area of Pakistan. 46 pp., World Wide Fund for Nature-Pakistan, Lahore, Pakistan. 